\title{
Plotinus Arabus and Proclus Arabus in the Harmony of the Two Philosophers Ascribed to al-Fārābī
}

\author{
Peter Adamson \\ Ludwig-Maximilians-Universität München
}

As its title implies, the so-called Theology of Aristotle circulated as a work by Aristotle in the Arabic-speaking world. ${ }^{1}$ In fact though, it is a partial Arabic translation of the last three Enneads, the collection of Plotinus' treatises put together by his student and editor Porphyry. Though it is generally accepted that the Theology was a major source for Neoplatonic ideas in the Islamic world, much research remains to be done in discovering when and by whom it was read, and how exactly it was used by later readers. This paper will deal with the earliest, and perhaps most famous, allusion to the Theology in a philosophical work. It comes in the Harmony of the Two Sages, the two sages in question being Plato and Aristotle. ${ }^{2}$ The concern of the author, who according to the manuscript tradition is none other than al-Fārābī, is to dispel a widespread impression that Plato and Aristotle conflict in their teachings. While admitting that there are important differences between the two, not least in their mode of exposition and philosophical method, the author wants to say that their doctrines are in fundamental agreement. He refers, more than once, to the Theology in an effort to make this case.

Both the Theology and the Harmony have been intensively studied in recent years. Leading the way on the Theology has been Cristina D'Ancona, who has also written an interesting piece on the harmony between Plato and Aristotle in Arabic philosophy, among other significant article-length studies related to our

1 For a previous study of the text, in which I do not say much about the Harmony, see Adamson 2002.

2 I will cite from section numbers in the edition of Abū Nașr al-Fārābī, L'Harmonie entre les opinions de Platon et d'Aristote, texte et traduction, ed. and trans. F.W. Najjar, D. Mallet (= NM). I have also consulted the superior edition in al-Fārābī, L'armonia delle opinioni dei due sapienti il divino Platone et Aristotele, ed. and trans. C. Martini Bonadeo (= Mв). For an English translation, which uses the NM section numbers, see Alfarabi. The Political Writings, "Selected Aphorisms" and Other Texts, transl. C.E. Butterworth. 
theme. ${ }^{3}$ Then there is an improved edition of the Harmony along with Italian translation, and extensive notes, by Cecilia Martini Bonadeo. These studies add significantly to our understanding of both texts. The following is to a large extent just a footnote to their work and the scholarship of others, especially Fritz Zimmermann and Gerhard Endress.

I have two broad goals. First, I will try to explain the rather complicated textual situation surrounding this appeal to the Platonism of Aristotle's Theology in the Harmony of the Two Sages. This situation can be summed up as follows: not only is the Theology not by Aristotle, but the text to which the Harmony is referring is not the Theology of Aristotle as we know it, and the Harmony itself may not be by al-Fārābī either. My hope is that it may be useful to offer an overview of this messy philological context, even if I do not have much of substance to add to what has been established in the aforementioned studies. My second, and hopefully more original task will be to answer the following question: how exactly do the citations of the Theology help the author of the Harmony to make his case? As we'll see, there is more to this question than meets the eye. It is not simply a matter of making Aristotle into a (Neo-)Platonist. For, with his confident ascription of the Theology to Aristotle, the author of the Harmony runs a significant risk of making Aristotle disagree not just with Plato, but with himself.

\section{The Texts}

First then let us turn to the textual situation, beginning with the question of the authenticity of the Harmony. Though, as already noted, the work is ascribed to al-Fārābī in the manuscripts, this authorship has been doubted, especially by Joep Lameer and Marwan Rashed. ${ }^{4}$ Their objections are based on both style and content; of these the latter seem the more significant to me, given that there is a degree of stylistic variation within the undisputed Farabian corpus. Lameer lists a number of apparent philosophical errors in the Harmony, while Rashed mounts a case that the very thesis of the harmony between Plato and Aristotle, along with other doctrines in the text, would fit better with the group surrounding the Christian thinker Ibn 'Adī. For instance, al-Fārābī would not, like the author of the Harmony, accept that providence concerns particulars, did not think that God wills the world to exist with a first moment in time, and was well aware that Aristotle rejects the Platonic theory of Forms.

3 Plotino, La discesa dell'anima nei corpi (IV 8[6]); D'Ancona 2006.

4 Lameer 1994; Rashed 2009. 
Possible answers to these concerns have been offered by Mallet, Najjar, Genequand, Martini and (in a preface to Martini's edition) Gerhard Endress. One proposal is that differences between the Harmony and the rest of the Farabian corpus could be explained if we said that the Harmony is an early, even juvenile, work. Endress thus suggests that it could be one of his first writings, a proposal which has more recently been echoed by Damien Janos. ${ }^{5}$ On this interpretation, the Harmony might well manifest an understanding of Plato and Aristotle, and an approach to various philosophical questions, that the mature al-Fārābī came to reject. On the other hand, the text refers back to numerous previous writings, which suggests that our author is well launched onto his career. But on the bright side, from the authenticity point of view, one such back-reference is to a commentary by the author on the Nicomachean Ethics. As Martini points out, al-Fārābi is one of the few to have written such a commentary in Arabic.

I will not argue for any firm view about authenticity here, but would like to make some suggestions regarding the intellectual profile and approach of our author. It does not seem to me that the Harmony was, as Lameer suggests, written by someone who is philosophically amateurish. However, it does seem to be written by someone who is reluctant to delve too far into the subject-matter and display his full understanding of the issues at stake. A crucial theme that runs throughout the work is the contrast - so familiar from Quranic exegesisbetween the outer and inner meaning of a text, the zāhir and the bātin. ${ }^{6}$ The author freely admits that Plato and Aristotle seem to disagree, so that there is a superficial disharmony between the two. His main aim is to reveal that this is indeed just an appearance, zāhir rather than bātin. Another repeated refrain is that the author aims at brevity. This is of course a common trope in Arabic philosophical literature, often enough found in very long-winded texts. But the Harmony is not a long-winded text. It offers only cursory treatment of a large number of complicated philosophical issues. We need not suppose that the author is dropping hints for the initiated reader while trying to leave everyone else in the dark. My point is rather that the author's goal will be satisfied if he can undermine what he sees as a superficial interpretation, according to which Plato and Aristotle disagree on fundamental philosophical topics. For this purpose, it is enough for him to challenge the disharmony reading, and then merely to gesture at the fuller story of their harmony. Spelling out that story in each case would exceed the bounds of his brief.

5 Janos 2009.

6 For an example, see the text cited below, p. 185 . 
This pattern is well illustrated by the notorious passage in which our author refers to the authenticity of the Theology to establish that Aristotle did believe in Forms, despite his attack on that doctrine in the Metaphysics:

We find Aristotle, in his book on Lordship known as the Theology, affirming the spiritual Forms and stating clearly that they exist in the world of Lordship. If these statements are taken at face value, then one of three things must be the case: either they are contradictory, some of them are [really] by Aristotle and others not, or they have meanings and interpretations that bring their inner teachings (bawațin) into agreement, and in the process allow their outer statements (zawāhir) to concur. ${ }^{7}$ Thinking that Aristotle, despite his proficiency and intense vigilance, and the sublimity of these objects, that is, the spiritual Forms, would contradict himself within a single science, namely the science of Lordship, is implausible and repugnant. But the idea that some of [the statements] are Aristotle's and others not is still more implausible, since the books that include these statements are too widely known (ashhar) for any of them to be thought inauthentic. It remains only that they have interpretations and meanings that, once revealed, will eliminate doubt and confusion.

Harmony, мм §66; м в 68-69 = Т1

Views on this passage diverge sharply. Some, like Miriam Galston and Charles Butterworth, think that the author is well aware that Aristotle did not write the Theology. Butterworth goes so far as to remark, "he must surely have known [it] to be spurious." Galston likewise finds it incredible that al-Fārābī, of all people, would sincerely appeal to a widely shared opinion to secure the authenticity of the work. But Martini, rightly I think, dismisses this "dissimulation" reading. ${ }^{8}$ She also makes the good point that in principle at least, the authenticity of the Metaphysics is just as much in question here as that of the Theology.

However, the passage clearly involves a tacit admission that someone might worry about the authenticity of one or the other text. If so, it is of course the Theology that stands under suspicion, not the Metaphysics. This suggests that, like Avicenna, who will later remark that there is "some doubt" about the work, ${ }^{9}$ the author realizes the ascription is not beyond dispute. Yet he feels free to dis-

7 This follows M. Bonadeo in retaining the reading of Najjar, and not the alternative reading adopted by Butterworth. M. Bonadeo translates "e grazie a questo queste affermazioni divengono compatibili anche con il loro senso apparente."

8 Transl. M. Bonadeo 2008, p. 216.

9 In his Letter to Kiyā, translated in Gutas 1988, p. 63. 
miss the problem in a rather casual manner. Of course, it fits his purpose to consider the Theology as authentic. After all, his point in citing it is to undermine the widespread impression that Aristotle is a critic of Plato (as he says at the beginning of the work, §1, referring to "most people nowadays," akthar ahl zamāninā). People who think this are, he assumes, also likely to accept the authenticity of the Theology, because it is so "famous." ${ }^{10}$ Whether the Theo$\log y$ is really by Aristotle is, in a sense, neither here nor there. The point is to expose an incoherence in the superficial approach to the two philosophers that he is trying to undermine. This rival approach takes at face value evidence in the Metaphysics showing that Aristotle rejected the theory of Forms. Yet, our author assumes, its proponents will also admit that Aristotle wrote the Theology, which emphatically accepts the existence of Forms. As the author himself points out, this shifts the dilemma: we should not worry so much about Aristotle's disagreement with Plato, as about Aristotle's disagreement with Aristotle. His solution to that new dilemma remains tacit in this section of the Harmony, or so I shall argue below. For now, I just want to point out that invoking the Theology serves a rather modest aim, namely to problematize the superficial disharmony thesis, and to suggest that an alternative interpretation is necessary, even if no such interpretation is given here in full.

This brings us to the question of why our author would think in the first place that the Theology is by Aristotle, and even think that it is famously a work by Aristotle. Obviously, this statement presupposes that the Theology is already circulating under Aristotle's name, so we can rule out that the Harmony itself played a key role in generating the pseudonymous attribution, though it may have helped to perpetuate that attribution. To make a long story short, the most likely explanation would instead seem to be the one offered by Zimmermann, namely that a prologue attached to the Theology gave readers the impression that what followed was an Aristotelian work. ${ }^{11}$ The prologue seeks to situate the teachings found in the Theology within the framework of Aristotle's philosophy, and this misled subsequent readers and scribes into thinking that Aristotle was actually the author of the text.

Here we come to a further issue, and one that will provide the answer to a still further question that may be on some readers' minds: what is this paper about the Theology of Aristotle doing in a book on the reception of Proclus? The

10 As M. Bonadeo suggests translating ashhar, criticizing Galston's rendering "generally accepted."

11 Zimmerman 1986, p. 110-240. However in his "Proclus Arabus Rides Again," Zimmermann presents evidence that the Kindī circle could have been responsible for mislabeling the treatises gathered in the collection known as the Theology. 
answer is that, on Zimmermann's account, the prologue was appended not just to the Arabic translation of Plotinus, or some version thereof, but to a whole collection of texts (a so-called "metaphysics file") that included Arabic versions of writings by Proclus and Alexander of Aphrodisias..$^{12}$ In particular, it included a partial Arabic translation of Proclus' Elements of Theology $(=\mathrm{ET})$. A star witness in Zimmermann's case for this conclusion is none other than the Harmony. In the section of the work devoted to showing that Plato and Aristotle agreed in upholding the world's atemporal creation from nothing, the author of the Harmony appeals to the Theology in the following terms:

Whoever looks into his [sc. Aristotle's] statements about Lordship in the book known as the Theology will be in no doubt as to his affirming the Maker and Originator for this world. This is so evident in those statements that it can't be overlooked. There, he shows that the Creator, the exalted, originated matter from nothing, and that it became bodily thanks to the Creator, great be His praise, and from His will; and then it was put in order. He has shown too, in the Physics, that the universe cannot have come to be through chance and coincidence, and likewise in On Heaven and the World. He proves this on the basis of the astounding mutual arrangement found in the parts of the world. He has there explained the topic of causes, how many they are, and established the agent cause. Also he has explained there the source of generation and motion, and that it is neither generated nor moved. Just as Plato, in his book called Timaeus, showed that everything that is generated is necessarily generated from a cause that generates it, and that what is generated is not a cause for its own generation [i.e. the generative cause must be something else, not the thing itself], so Aristotle showed in his book Theology that unity exists in every multiplicity [cf. Elements of Theology §1], because any multiplicity in which no unity exists would be utterly infinite. He provided clear demonstrations for this, as when he says that every one of the parts of the multiple is either one or not one; but if it is not one, it must be either multiple, or nothing. But if it is nothing, then no multiplicity can be assembled from it; and if it is multiple, then what is the difference between it and multiplicity? From this it also follows that the infinite is greater than the infinite. Furthermore, he shows that anything in this world that has unity in it is both one and not one, in different respects [cf. Elements of Theology §2]. If then it is not truly ( fi l-haqiquati) one, 
but rather, unity [merely] exists in it, then unity is different from it and it is different from unity [cf. Elements of Theology §3-4]. Again, he shows that the True One is that which gives unity to other existing things. Again, he shows that the multiple is doubtless posterior to the one, and the one prior to the multiple [cf. Elements of Theology §5]. Again, he shows that every multiplicity that is near to the True One is less multiple than the one that is further away from it, and vice-versa.

Harmony Nм $§ 56$; м в 64-65 = Т2

As my bracketed insertions show, the author is clearly thinking not of anything in Plotinus, but of the opening propositions of the Elements of Theology. This was already noted by Endress in his Proclus Arabus, who remarked that our passage "nahezu wörtlich aus unserer Version von propp. 1-3 zitiert." I actually see allusions to propositions 4 and 5 as well. The last sentence is more difficult to anchor securely in any particular source. The "closer and further away" idea

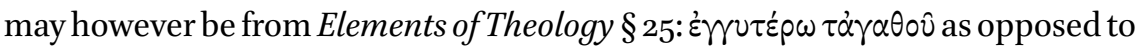
$\pi \circ \rho p \omega \dot{\tau} \varepsilon$ pov (see also § 28, §62). To this we can add that the reference to Forms in T1 can also be linked to the Arabic Proclus - specifically, to the Arabic versions of $\S_{15-17}$, which are the very propositions that follow the first five propositions in the manuscript studied by Endress. The upshot is that when the author of the Harmony refers to "the Theology," we should take him to be alluding not to the Theology of Aristotle as we think of it - a partial version of the Arabic translation of Plotinus produced in al-Kindī's circle-but rather to a perhaps larger text which in any case included material from the Arabic version of Proclus' Elements.

So much for the historical circumstances surrounding these notorious allusions to the Theology in the Harmony ascribed to al-Fārābì. Now let us turn to a rather different question: why exactly does the author of the Harmony think that these allusions can help him to establish a fundamental agreement between Plato and Aristotle? As I've already noted, this move is in a way obvious, and in another way deeply problematic. Obvious because a Neoplatonic Aristotle is an Aristotle who may be much more easily reconciled with Plato, but deeply problematic because a Neoplatonic Aristotle is one that will be difficult to reconcile with Aristotle's other writings. Given that our interest here is the reception of Proclus and not Plotinus, I will approach this problem by looking at a section of the Harmony that seems to be based on the Arabic version of 
the Elements of Theology, passing over the verbatim quotation from the Arabic Plotinus (at N/M § 75; M B 74).

The section of the Harmony featuring T2, which represents the work's clearest dependence on the Arabic Proclus, is devoted to the question of "the universe's being eternal or created, and whether it has a maker who is its efficient cause, or not" (N/M §53; M в 63). It may seem that Aristotle denies this, given that he mentions the eternity of the universe as a disputed issue in the Topics, ${ }^{13}$ and clearly states in On the Heavens that "the universe has no temporal beginning (laysa la-hu bad' zamānī )" (N/M §55; M B 63). The so-called Theology is then invoked in $\mathrm{T} 2$ to provide contrary evidence, to show that Aristotle did indeed believe in a maker for the universe and denied its eternity. But why is the material from the Theology, which here means the Arabic Proclus, even relevant? It seems surprising, not to say perverse, that he should choose to cite of all people Proclus, author of the set of eternalist arguments that provoked one of Philoponus' two polemics on the issue. Damien Janos has urged us to see the Harmony within the context of the Christian philosophers of Baghdad, who may have been under the influence of those very polemics of Philoponus. ${ }^{14}$

Persuasive though Janos' point may be, it does not answer the question of why the author of the Harmony should have thought it useful to cite the Theo$\log y$ at this juncture in his argument. It may seem that an easy answer is available. As we just saw, this part of the Harmony is framed as answering a two-part question: not only whether the universe is eternal, but also whether it has a "maker (șānic)" and "efficient cause ('illa fā ila)." While the Arabic Plotinus and Proclus offer no help to the author on the first issue, they are unambiguously helpful on the second. The Arabic Plotinus and Liber de causis both speak of "creation ('ibd $\bar{a}), " 15$ and the opening propositions of Proclus' Elements of Theology that lie behind T2 make the First Principle a cause for all things. The identity between Aristotle's God and this First Principle, a "true One" who is the source of all unity, is then secured with a reference to Metaphysics book Lambda which, our author tells us, "proves the unity (wahdāniyya) of the Cre-

13 Later this same passage from the Topics will be cited by Maimonides and Thomas Aquinas to cast doubt on Aristotle's commitment to eternalism (see e.g. Thomas Aquinas, Summa theologiae I Q 46 a.1 resp.). Notice that for the author of the Harmony, it plays the very different function of casting doubt on Aristotle's commitment to creationism.

14 Janos 2009, p. 6. Unlike Rashed, who has also pointed out resonances between the ideas of Ibn 'Adī and the Harmony, Janos thinks this may be made compatible with Farabian authorship. We need suppose only that the Harmony is an early work written while alFārābī was under the influence of his Christian teachers. See above for the difficulties of this chronological proposal.

15 Cf. Endress 1973, p. 209, 231. 
ator" (N/M § 57; M в 65). His interest in God's agency is further demonstrated by an allusion to a lost work of Ammonius (known to us through a summary in Simplicius), which argued that Aristotle's divine principle is indeed an efficient cause $\left(\mathrm{N} / \mathrm{M} \S 58\right.$; мв 66). ${ }^{16}$

While this seems to exhaust the author's explicit rationale for citing the Theology, we should probe for a deeper explanation of its relevance. He needn't paraphrase the first several propositions of the Elements of Theology to make the point that the Neoplatonica Arabica accept a first causal principle. And of course, we have yet to understand the precise relationship between asserting such a causal principle and denying the eternity of the universe. As Janos has stressed, our author is not merely asserting that God is an efficient cause. Rather, God exercises a unique form of efficient causality, capable of creating "without time (bi-lā zamān)" and without need for pre-existing matter. ${ }^{17}$ These two features of divine causation are linked, according to the author of the Harmony. An agent who needs to act in time on pre-existing matter is an agent who performs a motion, whereas God does not move when He creates. Most people fail to understand this. They "conceive of the first originator as being a body, and acting through motion and in time," and "are incapable of understanding how something can come to be from nothing, or be corrupted into nothing" (N/M §6o-61; мв 67-68). Such naive conceptions of God are to be found in many religious accounts, which describe the world as being fashioned out of material constituents like water (N/M §58; м в 66).

The author's goal then, is to show that Aristotle did not fall prey to these simple-minded notions. For this sake he can appeal to the idea that time is generated through celestial motion. ${ }^{18}$ If God is responsible for causing this motion then He cannot be acting in time. This, of course, is what Aristotle meant in On the Heavens when he denied a temporal beginning of the universe-not that the universe has always existed, but that God's agency is timeless $(\mathrm{N} / \mathrm{M} \S 55$; м в 64). The author can also appeal to the sequence of argument set forth by Proclus, and cited in T2. "Aristotle" here makes God, as a source of unity, prior to all multiplicity. Motion is multiple, which is precisely why it generates time,

16 Simplicius, In Phys., 1361-1363, in Sorabji 2004, 8(c). In another example of the way the author of the Harmony declines to go into detail, he says there is no need to present Ammonius' case in any detail "due to its fame (shuhra)." Compare this also to the remark about the notoriety of the Theology in T1.

17 Janos 2009, p. 3. These two features of divine creation are the same ones stressed by alKindī at On the Quantity of Aristotle's Books §vi.8, transl. Adamson, Pormann 2012.

18 The Aristotelian pedigree of celestial motion in particular as the source of time is provided by Alexander of Aphrodisias. See Maqālat al-Iskandar al-Afrūdīsífí l-zamān, p. 19-24, at 21. Trans. in Sharples 1982. 
unfolding "part by part."19 This is emphasized in the author's account of God's timeless causation:

The meaning of his saying that the world has no temporal beginning is that it is not generated one part after another (awwalan fa-awwalan $b i-a j z \bar{a} i h i)$ as, for instance, plants or animals are generated. For when something is generated one part after another, some of its parts precede others in time.

$\mathrm{N} / \mathrm{M} \S 55 ; \mathrm{MB} 64=\mathrm{T}_{3}$

Similarly, in T2 we were told that the Theology affirms the creation of matter from nothing. The thought here must be that matter is characterized by multiplicity, so that by showing the dependence and posteriority of all multiplicity on pure unity, Proclus has shown that matter cannot be independent of God's causation.

The Harmony also gives us an explanation for the methodological status of the argument found in the Theology. The author uses the metaphor of "ascending" from indubitable premises to establish a thesis. The metaphor is applied twice over (at N/M $\$ 57$; M B 65), first to describe the way that "Aristotle" goes on from the proof of true unity to "speak of the parts of the world, both bodily and spiritual," and how they were created; second, to describe the way that God's unity is established in the Metaphysics. In this way, even the characteristic "Euclidean" method of the Elements of Theology is situated within an Aristotelian framework. In the process, the author gives us a further clue as to why he cites the Theology so prominently: "Aristotle's" claims about the dependency of motion and matter on God are methodologically posterior to the more fundamental claim that God is a true One and source of all unity. Indeed, the timelessness of creation and the denial of pre-existing matter are nothing more than applications of the more general principle that whatever is many depends on the One.

From this it should be clear that the Harmony not only presents the Theology as being consistent with other works of Aristotle, but goes so far as to make it the key to his interpretation of those other works. It may seem that Aristotle is thus being "Platonized" so as to agree with the Timaeus. But actually, the reverse is true. It is rather the Timaeus that is assimilated to the doctrines of

19 Again, the idea that time is characteristic of God's multiple creation and not God as the True One is already found in al-Kindī. See his On First Philosophy, § I.5 (God is the "cause of time"), §vi.9 (time's connection to motion), §XIX.4 (God is not in motion). 
the "Aristotle" who emerges from the author's reconciliation of the Theology to the Metaphysics and On the Heavens. ${ }^{20}$ This is particularly clear from the way that Plato is said to deny the existence of matter prior to the creation of the universe. It's a rather surprising interpretive claim, since in the Islamic world Plato was frequently made a leading representative for the idea that the universe was fashioned with some first moment and from some pre-existing material. The Harmony simply assumes that the Timaeus' affirmation of a creator God rules this out, depending (as T2 shows) on the Theology to establish the correct meaning of terms like "creator" and "originator."

Let us now move on to the issue of Platonic Forms, which provides the context for T2 and its allusion to the problem of the authenticity of the Theology. As usual in the Harmony, the author begins by setting out prima facie evidence of a disagreement between the two great sages. Here the problem is that in his Metaphysics, Aristotle makes clear his rejection of Plato's Forms (N/M §65; м в 69). He cites as one problem raised by Aristotle the fact that there will be separate mathematical entities like surfaces and solids in addition to those we find in the sensible world. For this objection, scholars have cited Metaphysics A.9, B.2, Z.14, and M.2, all of which accuse Plato of effectively "duplicating" our world by positing another world of separate Forms. A somewhat less familiar idea found here in the Harmony is that Plato is committed to additional kinds of knowledge or science in the realm of the Forms. For in addition to the geometrical objects in that realm,

there will be sciences ( 'ulüm) there, like the sciences of the stars and the sciences of melodies, and of both composed and uncomposed sounds, and of medicine, geometry, of both rectilinear and curved magnitudes, and of hot and cold things and in general, active and passive qualities, and of universals and particulars and matters and forms.

Harmony $\mathrm{N} / \mathrm{J} \S 65 ;$ м в $69=\mathrm{T}_{4}$

Now, it is true enough that on Aristotle's interpretation the Platonic theory makes Forms the objects of knowledge. This emerges not only from various

20 Here, I agree with Martini Bonadeo, who writes (p. 204-205) that the Theology is a key to resolve the apparent tension between On the Heavens and the Timaeus. 
passages of the Metaphysics but also the little treatise On Ideas (Peri Ideon) preserved in Alexander's commentary on the Metaphysics. ${ }^{21}$

Here though, the Harmony is saying that there will actually be a science or knowledge that is itself a Form. This is less prominent in Aristotle's polemics, but can be found for instance at Metaphysics B.2, which tries to force on the Platonist a distinction between different kinds of medical sciences, one of which will be "medicine in itself" (997b28-30). The Harmony, typically enough, states that this consequence is ridiculous without really explaining why. In fact, the objection was already mentioned by Plato himself, indeed singled out as the greatest difficulty for the theory of Forms in the first part of the Parmenides. There, Plato has Parmenides warn that if knowledge is relational, and if Forms are related to one another and not to their participants, then Forms will be known only by the divine Form of Knowledge. In that case, neither will we mere humans be able to know Forms, nor will God have any knowledge of our world (Parmenides 133b-134e).

The reason I dwell on this is that it will, I think, help us to make sense of what happens in the Harmony following on the author's allusion to the Theology. I've already noted that that allusion seems to cause a problem, rather than solve one. Why would Aristotle critique the Forms in the Metaphysics, only to accept them in another work? It may seem that the author fails to address this question, or is even oblivious to it, given that he never returns to say anything about the Metaphysics. Instead, he seems to digress into a consideration of the general problem of describing God. In terms remarkably close to those used by al-Kindī and the texts produced in his circle, the author writes:

Because the Creator is by his very being (anniyya) and essence distinct from all other things, and this in a more noble, excellent and elevated way, nothing relates to Him in His essence or shares anything in common with Him, or is like Him either strictly speaking (haqīqatan) or metaphorically (mujāzan).

Harmony $\mathrm{N} / \mathrm{J} \S 67 ; \mathrm{MB} 7 \mathrm{O}=\mathrm{T} 5$

He even marks the section from which this quotation is drawn as a kind of digression, as is clear from the sequel:

Now let us return to where we left off and say: given that God, the exalted, is living, willing, and the originator of this world with all that is in

21 See Fine 1993, at 79-8o of the Greek text. 
it, is there any way to deny that the conditions for one who is alive and wills include forming a view (tașawwur) on what one wills to do, and the presence of forms (suwar) of what one wills to undertake in one's self (dhāt), may God be exalted above all comparison! Furthermore, because His essence is enduring with no change or alteration possible for Him, whatever is in His realm is likewise enduring without disappearance or alteration. If there were no forms and models for existing things in the essence of Him who is living, willing, and makes them exist, then what is it that He makes exist, and towards which pattern would He turn for whatever He acts and originates? Surely you know that whoever denies this idea in the case of the living, willing agent is forced to say that $\mathrm{He}$ brings things to be at random and foolishly, with no purpose and without turning towards any purpose intended by His choice. But this is most appalling.

Harmony $\mathrm{N} / \mathrm{J} \S 68 ; \mathrm{MB} 7 \mathrm{O}=\mathrm{T} 6$

The author seems to be ignoring the points he has just made in the apparent "digression" at $\mathrm{T}_{5}$. Rather than scrupulously avoiding the ascription of any attribute to God, he insists that we must speak of the Creator as willing and knowing. This is why both Plato and the Aristotle of the Theology accept Forms: there must be divine knowledge, given that only a knowing agent could have created the universe we see around us, and if God has knowledge then there must be divine and paradigmatic Forms to serve as fit objects for that knowledge. How can the author say these things in light of the structures expressed in T5? Well, he has also admitted that we cannot avoid using language to describe God. When we do so, we apply "synonymous" language "in a more noble and elevated way."22 For example, when we say that God is "alive" we mean "that $\mathrm{He}$ is alive in a more noble way than the one we know from any living thing lower than Him" (§67).

I would like to suggest that the juxtaposition of $\mathrm{T} 5$ and $\mathrm{T} 6$ is intended to echo the tension between Aristotle's Metaphysics and what our author knows as the Theology of Aristotle. On the one hand, Aristotle is well aware that strictly speaking, there can be no talk of knowledge, ideas, or Forms in God-since there can, strictly speaking, be no talk of God at all. But with this caveat in mind, we may allow ourselves to say (for instance) that God does have knowledge. It

22 See also §70: "since necessity stands as an obstacle and intervenes between us and that, we limit ourselves to existing utterances, forcing ourselves to bear in mind that the divine meanings we express by means of these utterances are of a more venerable species and are other than we imagine and conceptualize" (transl. Butterworth). 
is this less relaxed mode of discourse that Aristotle uses in his Theology. The solution works for the objects of knowledge as well as for knowledge itself. We cannot really affirm that there are separate mathematical objects like lines and surfaces apart from the ones we know - as Aristotle points out in the Metaphysics. Nonetheless, given that God was able to make things that have lines and surfaces, we should be prepared to admit, using language in a more extended fashion, that there are ideas of lines and surfaces in God's mind. As the author stresses ( $(69)$, this is very different from asserting that there are further realms akin to our universe, but populated with Forms instead of sensible objects. That position, the one critiqued in Aristotle's Metaphysics, would compromise the transcendence of the divine by making the immaterial realm a mere duplicate of our own.

If this interpretation is correct, then it gives us an example of a pervasive feature of the Harmony, and one already noticed in the previous section of this paper, namely that tensions between Plato and Aristotle tend to be resolved by assimilating Plato to Aristotle rather than vice-versa. ${ }^{23}$ When late ancient Platonists defended the harmony thesis, they usually did so by intimating that Plato grasped and presented higher truths than those found in Aristotle. Our author does the reverse. It is the Aristotle of the Metaphysics who wisely cautions us against simply postulating duplicates of sensible things in a divine realm. And it is the Aristotle of the Theology who tells us the sense in which separate Forms could, with all the caution due when attempting to describe God, be postulated nonetheless. Forms are present in the mind of the Creator insofar as He has knowledge about what He is to create.

The passage also bears out the observation I made above, that the author tends to stop short of a full accounting of the philosophical issues about which Plato and Aristotle disagree. While he sometimes suggests that he could indeed give such a full accounting if he were to go on at further length, in the present context he adds another reason for his limited ambition: the topic is just too difficult. Thus he says $(\S 76 \mathrm{~N} / \mathrm{M} ; 75 \mathrm{MB})$ that as regards the question of higher principles and forms, establishing the inner harmony of Plato and Aristotle is mumtani', a word whose semantic range stretches from "very difficult" (Najjar/Mallet's translation) to "impenetrable" (Martini Bonadeo's translation) to downright "impossible." Like most interpreters nowadays, I myself would agree with the strongest version of that sentiment. It is impossible to reconcile the

23 A particularly striking case is Plato's theory of recollection, which is assimilated to Aristotle's empiricist epistemology at $§ 5$ 1. My thanks to Hanif Amin Beidokhti for his observation about the text in general. 
teachings of Plato and Aristotle on all these issues, and throwing the Arabic Plotinus and Proclus into the mix isn't liable to help matters. Still, one cannot blame the author of the Harmony for trying his best to do so. He is simply echoing a long-standing presumption among philosophers that these two sages must be in agreement. In his own way, he is pursuing the quintessentially Proclean project of drawing together what is diverse into a unity.

\section{Bibliography}

\section{Primary Sources}

Alexander of Aphrodisias, Maqālat al-Iskandar al-Afrūdīsī fí l-zamān, in 'A.R. Badawī (ed.), Shurūh 'alā Arisțū mafqūda fì l-yūnāniyya wa-rasāàl ukhrā. Commentaires sur Aristote perdus en grec et autres épîtres, Beirut, Dār al-Mashriq, 1971. Trans. in Sharples 1982.

al-Fārābī (Abū Naṣr), L'Harmonie entre les Opinions de Platon et d'Aristote, texte et traduction, ed. and trans. F.W. Najjar et D. Mallet, Damascus, Institut Français Damas, 1999. Italian translation: L'armonia delle opinioni dei due sapienti il divino Platone et Aristotele, ed. and trans. C. Martini Bonadeo, Pisa, Pisa University Press, 2008.

al-Fārābī (Abū Nașr), The Political Writings, "Selected Aphorisms" and Other Texts, trans. C.E. Butterworth, Ithaca, Cornell University Press, 2001.

Al-Kindī, On the Quantity of Aristotle's Books § vi.8, in Adamson, Pormann 2012.

Al-Kindī, On First Philosophy, in Adamson, Pormann 2012.

Ibn Sīna, Letter to Kiyā, translated in D. Gutas, Avicenna and the Aristotelian Tradition, Leiden, Brill, 1988.

Plotinus, La discesa dell'anima nei corpi (IV 8[6]). Plotiniana Arabica (Teologia di Aristotele, I e viI; "Detti del Sapiente Greco"), a cura di C. D’Ancona, Padua, Il Poligrafo, 2003 .

\section{Secondary Sources}

Adamson, P. (2002), The Arabic Plotinus: a Philosophical Study of the Theology of Aristotle, London, Duckworth.

Adamson, P., Pormann P.E. (2012), The Philosophical Works of al-Kindī, Oxford, Oxford University Press.

D'Ancona, C. (2006), "The Topic of the Harmony Between Plato and Aristotle: Some Examples in Early Arabic Philosophy," in A. Speer, L. Wegener (eds), Wissen über Grenzen. Arabisches Wissen und lateinisches Mittelalter, Berlin, De Gruyter, p. 379405 .

Endress, G. (1973) Proclus Arabus. Zwanzig Abschnitte aus der Institutio theologica in arabischer Übersetzung, Wiesbaden / Beirut, Imprimerie Catholique. 
Fine, G. (1993), On Ideas: Aristotle's Criticism of Plato's Theory of Forms, Oxford, Clarendon.

Janos, D. (2009), "Al-Fārābī, Creation ex nihilo, and the Cosmological Doctrine of K. alJam ' and Jawābāt," in Journal of the American Oriental Society 129, p. 1-17.

Lameer, J. (1994), Al-Fārābī and Aristotelian Syllogistics. Greek Theory and Islamic Practice, Leiden, Brill.

Rashed, M. (2009), "On the Authorship of the Treatise On the Harmonization of the Opinions of the Two Sages Attributed to al-Fārābī," in Arabic Sciences and Philosophy 19 , p. $43-82$.

Sharples, R.W. (1982), "Alexander of Aphrodisias On Time," in Phronesis 27, p. 58-81.

Sorabji, R. (2004), The Philosophy of the Commentators, 200-6oo AD: a Sourcebook in Three Volumes, London, Duckworth, vol. 2.

Zimmerman, F.W. (1986), "The Origins of the So-Called Theology of Aristotle," in J. Kraye et al. (eds), Warburg Institute Surveys and textsXI:Pseudo-Aristotle in the Middle Ages, London, Warburg Institute, p. 110-240.

Zimmerman, F.W. (1994), "Proclus Arabus Rides Again," in Arabic Sciences and Philosophy 4, p. 9-51. 